\title{
Teaching Practice About the Innovative Training Models Of Full-time Graduates
}

\author{
Wang Changtao* \\ Information and Control Engineering Academy, Shenyang \\ Jianzhu University \\ Shen Yang, China \\ e-mail: arnold0110@sina.com \\ * Corresponding Author \\ Han Zhonghua \\ Information and Control Engineering Academy, Shenyang \\ Jianzhu University \\ Shen Yang, China \\ Cheng Juan \\ Information and Control Engineering Academy, Shenyang \\ Jianzhu University \\ Shen Yang, China \\ Wang Xin \\ Information and Control Engineering Academy, Shenyang \\ Jianzhu University \\ Shen Yang, China
}

\author{
Chen Nan \\ School of Information \& Control Engineering \\ Shenyang Jianzhu University \\ Shenyang, China \\ Kan Fenglong \\ School of Information \& Control Engineering \\ Shenyang Jianzhu University \\ Shenyang, China \\ Zhang Dongwei \\ School of Information \& Control Engineering \\ Shenyang Jianzhu University \\ Shenyang, China \\ Wang Bin \\ Northeastern University at Qinhuangdao \\ Qinhuangdao, China
}

\begin{abstract}
Objective: To improve the abilities of full-time graduates, the Innovative Training teaching method will be discussed in this paper. Methods: Shenyang Jianzhu University conducted a new teaching practice using innovative training in the teaching process on full-time graduate students, and achieved significant results. Results: In teaching practice, teachers should pay attention to make regular instructional designs, to strengthen application oriented teaching methods, establish application oriented academic communication between teaching faculty and graduate students. Conclusion: It simplified the management of graduate teaching. It set up a campus and business cooperation engineering practice platform for graduates.
\end{abstract}

Keywords-Innovative; Training; teaching ; practice; teaching methods

\section{TEACHING CONTENT AND METHODS OF INNOVATIVE TRAINING PATTERNS}

Application and Effectiveness on theory of teaching; teaching methods, assignments, examinations and other reform initiatives to ensure the quality of teaching, Course groups to carry out research activities in front of each semester and courses, and the exchange of teaching methods. Using a unified syllabus, unified progress, uniform examination standards. In teaching methods, To make graduate training teaching innovation has distinctive characteristics of engineering training, each speaker teachers can skillfully use the training room training device to closely combine theory and practical teaching. For the training of graduate relevant professional system design capabilities to achieve business "distance employment", the main train graduate students' innovative teaching methods used are the following: a. The first time the class "project-driven" method to tell the content of graduate course design project, requiring knowledge and design should be covered. Expand the theory as a basis for teaching and training teaching, focus on training postgraduate to identify problems, analyze problems, problem-solving and innovative thinking and technology integrated application capabilities. To do is:

The first step: project research, postgraduate select design objects by comparison, Then do a systematic analysis to the design objects, determination subsystem category, control methods needed to develop curriculum design plan schedule. Postgraduate design objects can be freely selected, in order to fully mobilize the postgraduate creative thinking, and fostering creative ability.

Step Two: Project Design: postgraduate complete the project design according to the design schedule. Throughout the process, mainly is postgraduate's independent design, the teacher's role is only answering questions, process monitoring, and to summarize and generalize the common problems. In this process, the ability to analyze problems of postgraduate, the ability to solve problems will be effective workout. Let postgraduate courses system for a more comprehensive understanding.

The third step: project acceptance: Teacher acceptance and evaluation on postgraduate of the completed projects Postgraduate courses need to the report and reply, postgraduates and teachers to ask questions, according to the scoring criteria to give results. For outstanding works on display and reviews.

b. Case Law

Theoretical and practical training courses through the selection of the business case, break down tasks, organically integrated into the curriculum-related 
knowledge, so that the relevant academic and technical fields have a more intuitive and emotional understanding, complete control of the relevant technology.

c. "Teaching", "learning", "do" of the Trinity Methodology

Theoretical teaching often used this method, such as when part explain the equipment monitoring system, using edge questions, while practice, while explaining, guiding methods.

d. Intuitive Methodology

Through theoretical teaching animation, electronic lesson plans, electronic courseware, projection, video, pictures and other educational technology now, so that complex principle with a simple, emotional approach to show up. And selecting closely related real-life examples to explain effectively simplistic concept which is difficult to understand. Visualize, fully aroused interest and initiative of postgraduate.

e. Discuss and exchange method

In the course of teaching, the teacher and postgraduate often discuss intelligent building technologies critical applications, so that each postgraduate to actively participate and give postgraduate the opportunity to express their views.

f. Incentive Methodology

In the training process, often used between the team competition method, Contest Results credited formative assessment results. Encourage teamwork and develop creative problem solving ability. Practice has proved that this method is very effective.

\section{INNOVATIVE PROCESS DESIGN OF THE TRAINING MODE OF TEACHING}

Follow the postgraduate as the main body, teachers as a supplementary principles of instructional design process, comprising the steps of:

The first step: understanding of knowledge: the basic principles for building automation technology is the "must be enough" principle. Featured works by classic case of the application to teach, and good at abstract theory concrete, visualization, and then assisted advanced multimedia, animation technology. It allows postgraduate in a relaxed and pleasant atmosphere to put what you have learned to understand and accept.

Step two: Experimental demonstration: experimental demonstration and analyzed by teachers, postgraduate can understand the specific implementation of software configuration, so that joint theoretical and practical.

The third step: actual operation: Through the postgraduate hands-configuration software, prepare control strategy, switching logic, etc. to complete the training program, to further deepen the understanding of building automation technology.

Step four: Deepening Learning: Postgraduates Innovative training arranged curriculum design, each group selected a design object for system design, requested the preparation of various types of equipment subsystem control strategy, switching logic, time programs, etc., to select and configure the Direct Digital Controller, training postgraduate of innovation ability, logical thinking ability and system design capabilities.
In teaching methods, teaching methods often used are: Show syllabus, teaching schedule, teacher electronic templates, Postgraduate study to improve the teaching process of many elements of purpose and foreknowledge of the syllabus, teaching schedule, teachers' lesson plans, etc., due to various reasons, the traditional teaching of teachers patent. Graduate students will be learning the content, practice methods, means and so often in a passive state. Show these content allows for the students the opportunity to learn to predict the content, improve the relevance and the purpose of the postgraduate.

Well-designed courseware, through the creation of the problem situation, to stimulate students interest in learning, each instructor independently elaborate electronic lesson plans, courseware and instructional videos, electronic templates appropriate to add some video files, sound files, and also added a number of animation files, so that lessons become lively and interesting, so that students can learn the knowledge impressively; in courseware design, to create a relaxed and lively classroom atmosphere, abstract issues into practical engineering graduate is easy to understand the context, and through animation and other means, so that graduate students through the cognitive of familiar things to understand the theory knowledge.

Teachers in the classroom demonstration program, exercise capacity graduate preparation program, because the software configuration features a method for achieving control, speaker teachers while analysis, while implementation. Meanwhile teachers analyze, graduate preparation of their own control strategy, switching logic, etc., through commissioning download, identify deficiencies control methods, improve their preparation software configuration capability.

Through open discussion platform for students and teachers to improve students learning autonomy and participation from a focus on teachers "teach" to pay more attention to students "learning", help students more through independent study, exploratory learning to improve their skills. Construction of building automation technology network course for such learning to provide a guarantee. Teachers and students through open discussion platform for graduate students with interest, with questions, with answers, with a satisfied return, greatly improving the graduate study initiative. As shown in Fig. 1 


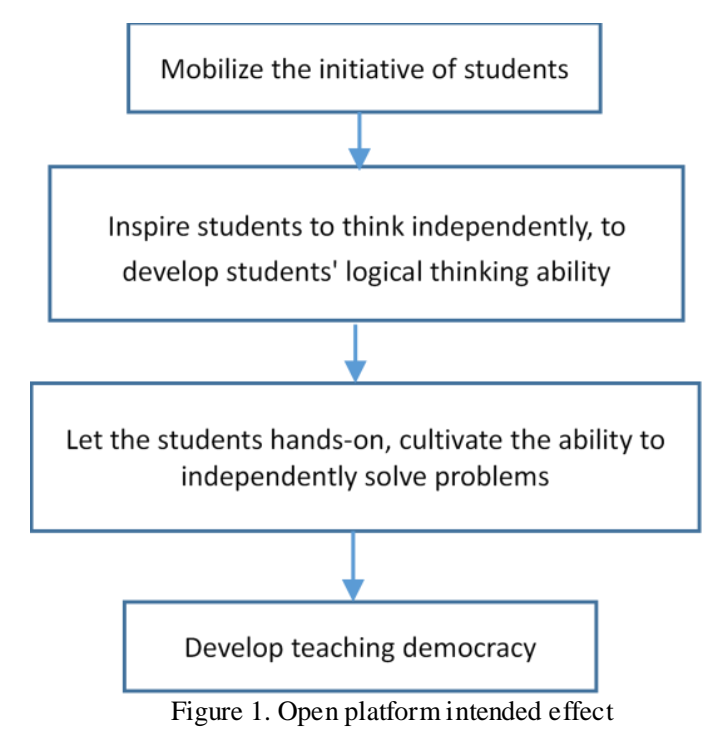

Graduate students retrieve relevant Web sites and a variety of ways to use a search tool habits, offer graduaterelated expertise related sites and forums address. Proposed in the teaching process timely question, it requires students to solve problems by retrieving pages, while the initial teaching graduate programs providing an important tool for book titles, after the teaching process often remind students take advantage of these tools. This is to train students self-learning ability of important content, but also the accumulation of knowledge is a very important means of. Once you've mastered these methods graduate accumulation of knowledge, its benefits are endless for life. A more objective assessment of the real evaluation of the graduate to learning and knowledge level, comprehensive application expertise to reflect the ability of students to solve practical problems, so that more students play individual potential. To overcome the one-sidedness of purely theoretical reaction Graduate Record Examination, avoiding the high scores but low capacity situation.

\section{REFLECTIONS ON PRACTICE TEACHING PROCESS}

Training practice in the engineering process and fulfill the "harmonious mutual aid" teaching ideas, using new teaching methods and teaching methods. Give full play to the initiative of graduate students and enthusiasm of teachers, thus graduate students in broadening the horizons of knowledge and improve students practical ability, innovation consciousness and ability as well as aspects of employability and others have satisfactory results. Technological innovation training achieved good results. School of engineering graduate students for basic training, covering the complex, jargon more, different professions, different students, different ethnic groups have different levels of graduate students will understand. "Individualized" modular training model. According to the practice of training content, each teacher has a clear, rational preset hearts are a few, starting from graduate practical training and flexible interpretation of the contents of, truly comprehensive development concerns graduate students.
So that different levels of students with varying degrees of development, so as to clarify responsibilities to build a harmonious practice teacher training body.

Strengthen communication and academic exchanges between teachers, effective protection of the ability to build a harmonious teacher teaching training practice in the engineering process, teachers only continue to improve their quality in order to build a harmonious engineering training practice effective teaching. On the one hand teacher training and awareness of lifelong learning continue to be strengthened, the academic exchange between teachers themselves continuously enhance the quality of professional services and the regulation of the teaching process management capabilities continue to improve. On the other hand, mental health, and openminded mood of teachers in practice and improve real-time graduate students master all kinds of problems arise.

Teaching simplify administration, from the system to protect the harmony taught engineering training practice. Currently, prevalent in teaching management quantify excessive, too rigid, too classroom program, mechanization, model of the phenomenon, the teaching process will inevitably lead to the rigid little angry. Engineering training in schools, the education authorities to create a relatively relaxed environment, the classroom teaching really gave teachers, teacher interaction with students, and actively build a harmonious classroom and training environments. We can see that a group of surveys in Table 1. Student evaluation of heuristic teaching method and traditional teaching method as shown in Table II. Scientific and technological innovation to expand the training and integrated training, especially postgraduate technological innovation projects, according to the content and experimental time on a regular basis or make an appointment to open experimental facilities. Through years of practice and exploration, the basic form of the "advance booking, self-learning, self-management, quality supervision," the open-Engineering Practice and Training Management Model. Promote the cultivation of postgraduates' innovation ability to meet the needs of graduate students "personality" of development. Comparison of two test results are shown in Table III.

$$
\text { Table I. Comparison Test }
$$

\begin{tabular}{|c|c|c|c|}
\hline Survey content & Option & $\begin{array}{l}\text { Experimental } \\
\text { Group }(\%)\end{array}$ & $\begin{array}{l}\text { Normal } \\
\text { Group }(\%)\end{array}$ \\
\hline \multirow{5}{*}{$\begin{array}{l}\text { Find yourself learning } \\
\text { materials, and be } \\
\text { proactive with the } \\
\text { teacher or the students to } \\
\text { explore the electrical } \\
\text { category of professional } \\
\text { knowledge and skills }\end{array}$} & Never & 0.91 & 0.8 \\
\hline & Seldom & 3.4 & 3.8 \\
\hline & $\begin{array}{l}\text { Some- } \\
\text { times }\end{array}$ & 14.9 & 15.8 \\
\hline & Often & 28.3 & 27.6 \\
\hline & Always & 51.4 & 52.6 \\
\hline \multirow{5}{*}{$\begin{array}{l}\text { Actively cooperate with } \\
\text { the teachers teaching in } \\
\text { the classroom }\end{array}$} & Never & 0.8 & 10.1 \\
\hline & Seldom & 3.4 & 16.6 \\
\hline & $\begin{array}{l}\text { Some- } \\
\text { times }\end{array}$ & 16.9 & 28.2 \\
\hline & Often & 26.1 & 14.7 \\
\hline & Always & 53.97 & 56.8 \\
\hline \multirow{6}{*}{$\begin{array}{l}\text { On the construction of } \\
\text { electrical specialty } \\
\text { thinking and behavior are } \\
\text { very active }\end{array}$} & Never & 1.03 & 10.3 \\
\hline & Seldom & 1.78 & 19.0 \\
\hline & Some- & 2.15 & 25.2 \\
\hline & times & & \\
\hline & Often & 11.68 & 16.7 \\
\hline & Always & 31.17 & 57.8 \\
\hline
\end{tabular}


Table II. STUDENT EVALUATION OF HEURISTIC TEACHING METHOD AND TRADITIONAL TEACHING METHODS.

\begin{tabular}{|l|c|c|c|c|}
\hline Group & $\begin{array}{l}\text { Cultivation } \\
\text { Of interest. }\end{array}$ & $\begin{array}{l}\text { Content } \\
\text { Vivid. }\end{array}$ & $\begin{array}{l}\text { Theory } \\
\text { With } \\
\text { Practice. }\end{array}$ & $\begin{array}{l}\text { Teaching } \\
\text { evaluation }\end{array}$ \\
\hline $\begin{array}{l}\text { Experimental } \\
\text { Group }\end{array}$ & 78 & 87 & 83 & 82 \\
\hline $\begin{array}{l}\text { Normal } \\
\text { group }\end{array}$ & 59 & 58 & 47 & 58 \\
\hline
\end{tabular}

Table III. COMPARISON OF THE TWO GROUPS OF TEST RESULTS.

\begin{tabular}{|l|c|c|c|c|c|}
\hline Group & $\begin{array}{l}\text { Excellent } \\
>90\end{array}$ & $\begin{array}{l}\text { Good } \\
(80-90)\end{array}$ & $\begin{array}{l}\text { Medium } \\
(70-80)\end{array}$ & $\begin{array}{l}\text { Pass } \\
(60-70)\end{array}$ & $\begin{array}{c}\text { Fail } \\
<60\end{array}$ \\
\hline $\begin{array}{l}\text { Experimental } \\
\text { Group }\end{array}$ & 78 & 87 & 83 & 82 & 1 \\
\hline $\begin{array}{l}\text { Normal } \\
\text { group }\end{array}$ & 59 & 58 & 47 & 58 & 8 \\
\hline
\end{tabular}

\section{CONCLUSIONS}

Practice has proved that the process of training in engineering practice, and actively implement the "mutual harmony," the practice of teaching the main line, good use of the advanced educational philosophy and technology, the engineering graduate practical ability to adapt to the knowledge economy, the environment, adapt to changes in the requirements of globalization. Information and Control Engineering Colleges Graduate engineering practice ability, innovation consciousness-round training, and comprehensively improve the overall quality and competitiveness of the graduate, played a significant role in promoting the work of professional degree dissertation research postgraduates.

\section{REFERENCES}

[1] Liuxiang Bing, Li Liguo, the Management Introduction to Strategic University [M]. Renmin University of China Press, 2006.

[2] Zhang Chuting forward. Curriculum and Teaching Philosophy [M]. People's Education Press, 2003.

[3] YuXiao,KongHanbing. The ability to guide the engineering practice pattern comparison and evaluation [J] . HIGHER EDUCATION OF ENGINEERING, 2011 (3) : 22-25.

[4] WangJie,TaoXinhong. Confucius' Idea of Moral Education Graduate Academic Ethics[J]. Education Observation (Early Publications).2015(27).

[5] Yin Xiaodong. The main factors affecting the quality of doctoral and postgraduate training study [D]. Southwest University 2014.

[6] Wang Xin, Huang Kuan, Gao Zhijun. The Primary Users' Signals Recognition Algorithm in Cognitive Radio Networks via KPCA and Random Forest[J].ICIC Express Letters,2015, 9(4):1083-1088.

[7] Wang Xin,Guo Lili,Ma Lina. Cooperative Spectrum Sensing Algorithm Based on Second User Selection and Random Forest Classification[J].ICIC Express Letters, Part B: Applications,2015, 6(3):845-850

[8] ZhangXiaolin. Research on the management and operation of local college sports Masters Degree graduate teaching $[\mathrm{J}]$. Education Observation (Early Publications). 2015(25).

[9] Li Qingxian. MSc employment quality research [D]. Beijing University of Science and Technology. 2015.

[10] LvPu,TaoYuping. Full-time Master of Engineering Quality Assurance System Construction[J]. China Electric Power Education. 2014(02).

[11] FengJiqing. Based Graduate Education Research and Exploration Team Tutorial System[J]. China Electric Power Education. 2014(02)

[12] GuoQi,HuangHuan. Graduate effective teaching case studies[J]. China Electric Power Education.2014(02). 